\title{
Drought sensitivity of Empetrum nigrum shrub growth at the species' southern lowland distribution range margin
}

\author{
Nils Hein $(\mathbb{D}) \cdot$ Julia Merkelbach $\cdot$ Katharina Zech $\cdot$ Stef Weijers
}

Received: 4 June 2020/ Accepted: 28 November 2020/Published online: 24 December 2020

(C) The Author(s) 2020

\begin{abstract}
The ongoing warming of the Earth's atmosphere is projected to cause a northward shift of species' distributions, as they track their climatic optimum. In the rapidly warming Arctic, this has already led to an increase of shrubs in tundra ecosystems. While this northern expansion of woody biomass has been studied relatively extensively over the last decade, little research has been devoted to shrub growth responses at the southern margins of Northern Hemisphere shrubs. Here, we studied shoot length growth, its responses to climate over the period 2010-2017, and differences in leaf C and N content of the evergreen dwarf shrub Empetrum nigrum, as well
\end{abstract}

Communicated by Christopher Carcaillet.

Supplementary Information The online version contains supplementary material available at https://doi.org/10.1007/ s11258-020-01107-z.

N. Hein $\cdot S$. Weijers $(\bowtie)$

Department of Geography, University of Bonn, Meckenheimer Allee 166, 53115 Bonn, Germany e-mail: stef.weijers@uni-bonn.de

N. Hein

The Zoological Research Museum Alexander Koenig, Adenauerallee 160, 53113 Bonn, Germany

J. Merkelbach

Division Energy, Transport and Climate Policy,

Wuppertal Institut Für Klima, Umwelt und Energie,

Döppersberg 19, 42103 Wuppertal, Germany as the vegetation composition and soil parameters at four sites located along a gradient of increasing dune age on the island Spiekeroog, northern Germany. The sites are located in the tri-national UNESCO world heritage site, the Wadden Sea. E. nigrum has a predominantly circum-arctic-boreal distribution and its southern distribution margin in European lowlands runs through northern Germany, where it is retreating northwards. We found a negative response to autumn (surface) temperatures and previous summer surface temperatures and/or a positive response to summer precipitation of E. nigrum growth, except at the oldest dune with the strongest $E$. nigrum dominance. Growth rates and plant species diversity declined with dune age. Our results suggest that E. nigrum growth is drought sensitive at its European southern range margin. We hypothesize that this sensitivity may form the basis for its northward retreat, which is supported by recent observations of E. nigrum dieback in

\footnotetext{
K. Zech

Department of Geography, Christian-Albrechts-

Universität Kiel, Ludewig-Meyn-Straße 14, 24118 Kiel, Germany
} 
Germany after the extreme drought in 2018 and model projections.

Keywords Browning - Dieback - Dune ecosystems · Plant distribution - Retreat - Shrub expansion .

Wadden sea

\section{Introduction}

Distribution ranges of boreal and Arctic plant species are projected to shift northward and upward in the northern hemisphere as a result of the warming of the Earth's atmosphere, as they track their climatic optimum (Settele et al. 2014). This has already led to a pronounced 'greening' of Arctic and alpine ecosystems, due to the immigration of taller species (Bjorkman et al. 2018) and an expansion of shrubs (Myers-Smith et al. 2011) in these ecosystems. Over the last decade, this northern expansion of, mainly woody, species has been studied relatively extensively (e.g. Myers-Smith et al. 2015). However, while this northern expansion of species ranges is well documented, the northward retreat of species from their southern-most range is less studied and little research has been devoted to shrub growth responses at the southern margins of Northern Hemisphere shrubs. Here, we focus on growth responses of the evergreen dwarf shrub Empetrum nigrum to climate at four sites located along a gradient of increasing dune age on the island Spiekeroog, northern Germany, near its southern distribution margin in European lowlands. The dwarf shrub species Empetrum nigrum has a largely circum-arctic-boreal distribution and its near-sealevel southern distribution margin in Europe runs through northern Russia, northern Poland, northern Germany, where it is retreating (Floraweb 2013), the Netherlands, and the British Isles. Further south in Europe, it becomes restricted to progressively higher elevations, and it is thus likely adapted to cooler climates (Bell and Tallis 1973). Empetrum nigrum is a key species in northern heathlands, and climate change will likely lead and has already led to shifts in its distribution (Wilson and Nilsson 2009; Buizer et al. 2012; Vowles et al. 2017; Vowles and Björk 2019; Kitagawa et al. 2020; Shevtsova et al. 2020). It is of special interest, due to its dominance in some ecosystems near its southern lowland distribution limit, including the Dutch and German barrier-island dunes (Isermann 2005). Although E. nigrum shrubs are not grazed upon, its berries are sometimes eaten, for example, by geese which may play an important role in its seed dispersal (Green et al. 2018). In addition, its berries are among the most harvested by Inuit in the Canadian Arctic territories (BoulangerLapointe et al. 2019). Some models predict an extinction of E. nigrum in the Wadden Sea by 2050, in the event of a temperature increase of $+2.5 \mathrm{~K}$ (Metzing 2010). The loss of this species will subsequently entail dramatic changes in the appearance and functionality of the dune ecosystems on these islands.

Black crowberry in Wadden Sea coastal dune ecosystems

Black Crowberry (Empetrum nigrum) is an important stabilizer of sand-dune systems on the Wadden Sea islands, because their dense cover protects the dunes from wind erosion. Large parts of the islands are dominated by this shrub. Severe drought events have been observed more frequently over the last decade in Central Europe (Bose et al. 2020), which will likely have an increasingly negative effect on the dune ecosystems (e.g. dry sand is much more exposed to wind erosion than wet sand) and its resident plant species.

The Wadden Sea, a unique coastal ecosystem, which became UNESCO World Heritage in 2009, located in the triangle between the Netherlands, Germany and Denmark, is currently threatened by various ecological changes. Recent developments suggest that changes are mainly driven by four factors: (i) global warming, (ii) invasive species, (iii) relative sea-level rise, and (iv) other human impacts (Trilateral Wadden Sea Cooperation 2018). However, with respect to climate change-related threats, the scientific insight regarding the Wadden Sea ecosystem is still scarce (Wadden Sea Board-Task Group Climate 2017). For example, the predicted sea-level rise (Grinsted et al. 2015; Jevrejeva et al. 2016) will likely have dramatic impacts on the Dutch, German and Danish coastline. The effects of the sea-level rise will include the erosion of natural and artificial flood protection and the salinization of fresh water resources along the respective coastlines. 
The sand-dune systems and thus the geomorphology of the Frisian Islands along the Dutch and German coast are strongly influenced by plants (Metzing and Gerlach 2001). Plants act as stabilizers of the sand and additionally accumulate large amounts of wind transported sand. Today's shape and structure of the barrier islands are the result of centuries of interplay between natural succession and human influences (Pott 1995). To enable ecosystem management in the future, it is essential to gain further understanding of the ongoing ecological dynamics of the Wadden Sea region.

To identify possible drivers of its northward retreat, we studied climate-growth relations and leaf carbon and nitrogen content in black crowberry (Empetrum nigrum) in a natural dune ecosystem that is dominated by this species, located on the island Spiekeroog, northern Germany near the southern range margin of its lowland European distribution (Floraweb 2013). Our research studies potential climatic drivers in the island's dune ecosystems, and how environmental changes might affect these systems. We made observations at four sites of different dune age and developmental stages. In addition, we measured soil parameters and plant species composition at these four sites. We wanted to study how dune age and related environmental parameters influence climate-growth relationships in and growth rates of Empetrum nigrum near its southern range margin in European lowlands, where it is retreating northwards. We expected decreasing nutrient availability with dune age, resulting in increased $\mathrm{C} / \mathrm{N}$ ratios in leaves, decreased growth rates, and a negative influence on E. nigrum growth of warm and dry climatic conditions.

\section{Methods}

Research area

Our study was conducted on Spiekeroog (Lower Saxony/Germany), one of the East Frisian Islands around $6 \mathrm{~km}$ off the German North Sea coast (Fig. 1a, b). Since 2009, the island has been part of the UNESCO World Heritage Wadden Sea, and it has a size of approx. $18.25 \mathrm{~km}^{2}$. Spiekeroog is a typical barrier island, with a relatively young history starting at the end of the last glacial maximum (LGM, approx. 20,000 years BP). Until the middle of the seventeenth century, the size of Spiekeroog was significantly smaller than today, but since the Harle River on the mainland was diked, sedimentation has caused the island to expand eastward, an ongoing process. Spiekeroog is often referred to as the most natural of the East Frisian Islands, due to its still largely intact natural dune ecosystems (Pollmann et al. 2018).

The seaward dune ecosystems show a beach parallel orientation with the youngest and smallest dunes present on the beach plains, and the oldest dunes in the inner islands (Gerlach 1993). Accumulations of sand develop in the lee-ward side of small obstacles, a process which, if continued, ultimately leads to the formation of new dunes. The first plant species to inhabit these nascent dunes is commonly the sand couch grass (Elymus farctus). As soon as the embryonic dunes reach a height of several decimetres and the influence of the sea decreases, E. farctus is commonly replaced by the European beach grass (Ammophila arenaria), typically the dominating species of white dunes. Ammophila arenaria develops vertical and horizontal rhizomes which continuously stabilize and increase the amount of accumulated sand; dunes on Spiekeroog reach heights of up to $25 \mathrm{~m}$ (Röper et al. 2013). As dunes age, soil development proceeds and more organic material is accumulated, and dunes become more species-rich (Pollmann et al. 2018). This next developmental step in the natural succession of the dune ecosystems are called grey dunes. Grey dunes are protected from sand movement by dense vegetation cover and show highest plant biodiversity in dry dune systems (Isermann 2005). Brown dunes are considered as the climax succession stage in natural dune systems. They are characterized by a shallower profile and low species diversity. North-facing slopes are dominated by Empetrum nigrum while southfacing slopes are dominated by lichens (e.g. Cladina spp.), bryophytes (e.g. Pseudoscleropodium purum, Pleurozium schreberi), and grey-hair grass (Corynephorus canescens). The four sampling sites included in this study were chosen for their age, stage of succession, and floristic composition.

\section{Sampling sites}

The sampling sites (Fig. 1a) were selected following the gradient of natural dune development from younger grey dunes in the north on the beach flats of the island, to older grey and brown dunes in the interior parts of Spiekeroog (Merkelbach 2014). 

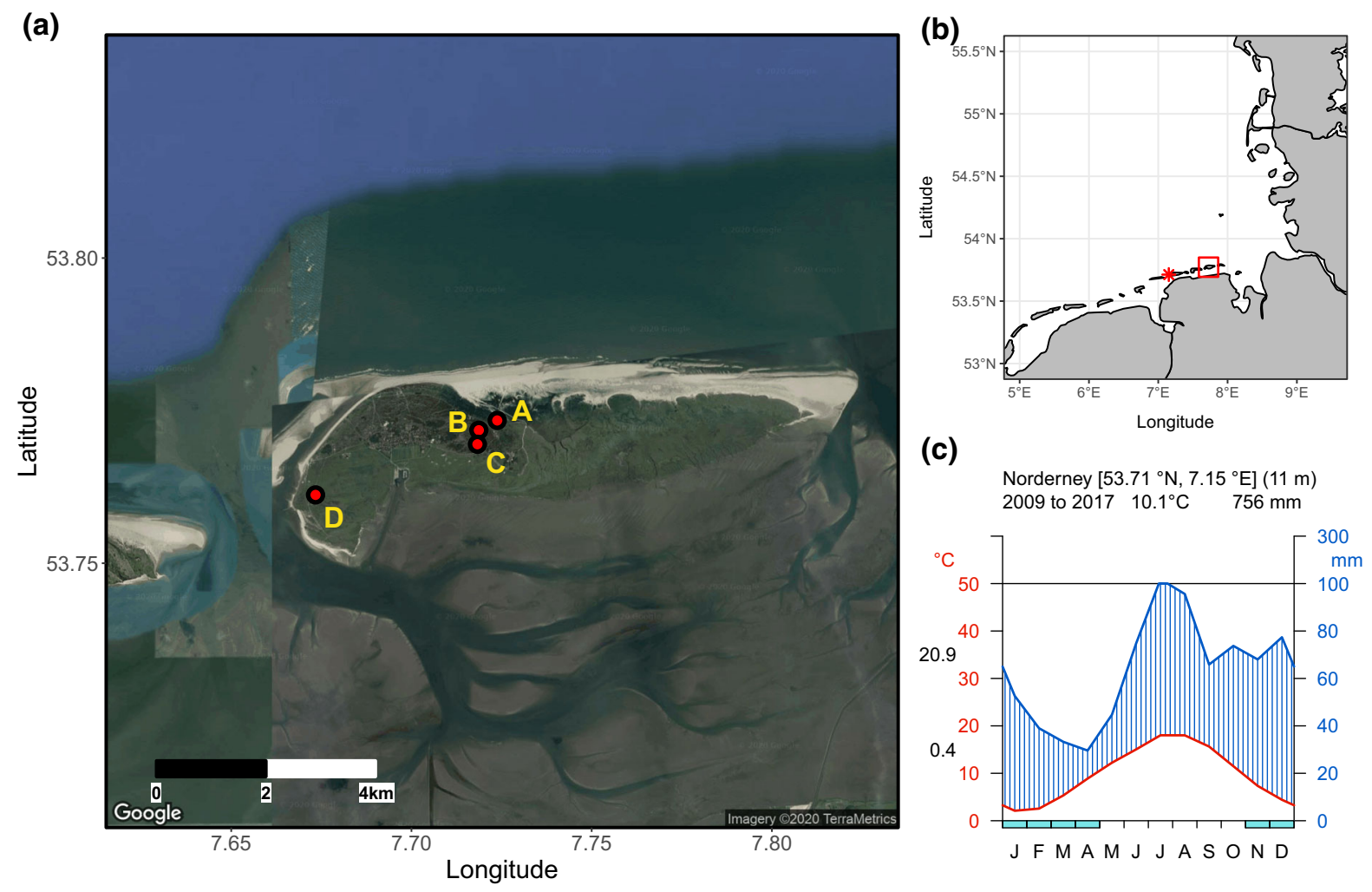

Fig. 1 Map showing the locations of the four different dune sites of different ages on Spiekeroog (a). Sites were sampled along a gradient of increasing dune age from youngest (A) to oldest (C and D). The location of Spiekeroog in the greater Wadden Sea area (b) is indicated with a red square. The location of the Norderney weather station is indicated with a red asterisk.

According to Drachenfels (2016), the biotope type for all sampled sites is 'Krähenbeere-Küstendünenheide' (KDE), which corresponds to the 'Empetrum nigrum type' following The Trilateral Monitoring and Assessment Programme (Petersen et al. 2014). This biotope type is characterized by dominance of Empetrum nigrum, and Polypodium vulgare on small subareas. It is the typical vegetation type on the north-facing slopes in grey and brown dunes.

Sampling site A $\left(53.7734^{\circ} \mathrm{N}, 7.7238^{\circ} \mathrm{E}\right.$, WGS 84) is on a younger grey dune with an estimated time of origin between 1938 and 1960 (Gerlach 1993). Sampling site B (53. $7718^{\circ} \mathrm{N}, 7.7187^{\circ} \mathrm{E}$, WGS 84) is a more developed phase of dune succession, an older grey dune. Its estimated time of origin is approximately around $1841-1938$. Site $\mathrm{C}$ is an even older site $\left(53.7695^{\circ} \mathrm{N}, 7.7183^{\circ} \mathrm{E}\right.$, WGS 84 ) and is classified as an old brown dune, with its origin being most likely
Climate diagram showing ambient temperature (red) and precipitation (blue) of Norderney for the period 2009-2017 (c). Values to the left of the temperature axis indicate the mean minimum temperature of the coldest month (January) and the mean maximum temperature of the warmest month (August)

around the period 1738-1841 (Gerlach 1993). In addition, we decided to include a fourth site, $\mathrm{D}$, which has approx. the same age as site $\mathrm{C}$ but is flooded every couple of years. Consequently, the nutrient availability should be higher than in the inner parts of the island. Site D is located in the south-western part of the island at $53.7612^{\circ} \mathrm{N}, 7.6734^{\circ} \mathrm{E}$ (WGS 84). It is isolated from the main-dune chain (sites A-C) that protects the inner island from flooding. The estimated age of origin is also determined to the years 1738-1841 following the schema of Gerlach (1993).

The sites were first visited on 3-6 November 2014 , i.e. after the growing season, and revisited on 5-6 March 2018, before the onset of the growing season. 
Species

Empetrum nigrum has a circumboreal distribution on the northern hemisphere with its European lowland range margin in northern Germany (Floraweb 2013). Empetrum nigrum is a much branched, evergreen dwarf shrub belonging to the family of Ericaceae. It grows on semi-humid soils and is an indicator for nitrogen-poor soils (Ellenberg and Leuschner 2010). In cold temperate ecosystems, E. nigrum quite often dominates in areas with nutrient-poor and low-acid soils. While pollination in E. nigrum is anemophilous, it mainly spreads via zoochory. The clonal growth of E. nigrum ensures that hardly any other species can settle in these areas, and it often comes to mat-like monospecific vegetation. It outcompetes most plants in late successional stages through allelopathy and resource competition, and it is a strong nutrient competitor (Tybirk et al. 2000). In addition, hardly any animals feed on E. nigrum, except for its fruits, which is another great advantage in competition with other co-occurring species (Tybirk et al. 2000). In Germany, it has been retreating northward in recent decades and has the status 'endangered' (Floraweb 2013). However, according to Walter \& Gillet (1997) Empetrum nigrum is not threatened on a global scale.

\section{Climate}

We extracted monthly climate data for the period 2009-2017 from the weather station Norderney (Station ID: $3631 ; 53.7123^{\circ} \mathrm{N}, 7.1519^{\circ} \mathrm{E} ; 11 \mathrm{~m}$ a.s.l., Fig. 1b) through the Climate Data Center of the Deutsche Wetterdienst (DWD 2019). The climate at our research area is temperate oceanic. Both the warmest and wettest months occur in summer, while all months can be considered humid (Fig. 1c). Although frost occurred at some point in the months November-April (2009-2017), no months had mean minimum temperatures below $0{ }^{\circ} \mathrm{C}$. The coldest month was January with a mean minimum temperature of $0.4{ }^{\circ} \mathrm{C}$, and August the warmest month, with a mean maximum temperature of $20.9^{\circ} \mathrm{C}$ over the period 2009-2017 (Fig. 1c). We chose this station, as it is the nearest Wadden island station (approx. $40 \mathrm{~km}$ distance), and therefore, the most representative for the climate at our sites on Spiekeroog. We extracted monthly mean air temperatures at $2 \mathrm{~m}$ above ground $\left({ }^{\circ} \mathrm{C}\right.$; hereafter 'air temperature'), monthly mean minimum air temperatures at $5 \mathrm{~cm}$ above ground $\left({ }^{\circ} \mathrm{C}\right.$; hereafter 'surface temperature'), monthly precipitation sums $(\mathrm{mm})$, and monthly sums of sunshine duration (hours) from this dataset and calculated seasonal means (temperature) and sums (precipitation, sunshine hours) for climate-growth analyses. The seasons were defined as Dec-Feb (winter), Mar-May (spring), Jun-Aug (summer), and Sep-Nov (autumn). In addition, we extracted monthly means and daily minimums, as well as mean maximum air temperatures at $2 \mathrm{~m}$ above ground for the period 2009-2017 to prepare the climate diagram for Norderney. The Walter-Lieth climate diagram (Fig. 1c) was created with the package 'climatol' in $\mathrm{R}$, version 3.5.3 (R Core Team 2019). Furthermore, we extracted self-calibrating Palmer Drought Severity Index (scPDSI) data (Wells et al. 2004) from the gridded CRU TS4.03 temperature and precipitation-based scPDSI dataset $\left(0.5^{\circ} \times 0.5^{\circ}\right.$ resolution; van der Schrier et al. 2013; Barichivich et al. 2019) for the grid with centre $53.75^{\circ} \mathrm{N}, 7.75^{\circ} \mathrm{E}$, representing our sites, for the period 2009-2017 via the KNMI Climate Explorer website (Trouet and van Oldenborgh 2013) and calculated seasonal means.

\section{Annual shoot length}

We sampled two $\times 25$ Empetrum nigrum branches at each of four sites along a gradient of increasing dune age (Fig. 1) on two different occasions: first in November 2014 and the sites were again sampled in March 2018. Consequently, a total of 200 shrubs (100 in 2014 and 100 in 2018) were sampled on the middle slope of the sampling sites, i.e. two $\times 25$ branches were taken for analysis in the laboratory at each of the four sites. All sampled plants were from north-facing slopes. The samples were taken along a line of approx. $50 \mathrm{~m}$ at the mid-slope of the respective dunes. Only plants of which branches had apparent healthy and green tips were sampled, thus knowing the last year of growth. In the laboratory, we measured annual shoot lengths retrospectively with $0.01 \mathrm{~mm}$ precision using a digital calliper. In E. nigrum, the end of each annual leaf cohort, and thus annual shoot length, can be detected through the occurrence of old flower buds (when present), which are formed towards the end of the growing season, and by shorter leaves with smaller distances between them (Buizer et al. 2012). On our samples, annual shoot length growth measurement of 
the last three to five years (first sampling) and one to four years (second sampling) was possible, resulting in continuous $E$. nigrum shoot length growth quantification for all sites over the period 2010-2017. Leaves and bark were missing from older parts of the stems and leaf scar distances no longer visible, preventing shoot length growth measurement further back in time.

We collected the green leaves formed in the last growing season (2017) of ten of the samples per site harvested in 2018. The leaves were first dried and then ground with a ball mill. Total $\mathrm{C}$ and $\mathrm{N}$ were determined in duplicate by dry combustion using a CHNS analyzer (Elementar-Analysensysteme $\mathrm{GmbH}$, Germany).

\section{Vegetation survey}

Vegetation composition was sampled by determining the frequency of all occurring plants at all sites. We used a frequency frame of $1.00 \mathrm{~m} \times 1.00 \mathrm{~m}$ containing 100 squares of $10 \mathrm{~cm} \times 10 \mathrm{~cm}$. Sampling followed the methods described in Kratochwil and Schwabe (2001). Five plots per sampling site were randomly chosen along the mid-slope of the respective dune in focus. All sites were north-facing slopes. The occurrence of each species was counted for each plot. We then calculated pooled frequencies for each site.

\section{Soil parameters}

At each site, three separate soil samples were taken mid-slope between the vegetation plots at depths of $10 \mathrm{~cm}$ and $30 \mathrm{~cm}(n=6)$. The soil samples were stored in a freezer to retain the original state of soil nutrients until further analysis in the laboratory. For further analysis, the soils were air dried at room temperature. All analyses were done in solutions made out of dried and then pestled soil material. Soil $\mathrm{pH}$ values were measured both in solutions of $\mathrm{CaCl}_{2}$ and $\mathrm{H}_{2} \mathrm{O}$, with inoLab WTW series ph $730 \mathrm{pH}$ meter with SenTlx 41 probe in the laboratory following the directions of DIN ISO 10390: 2005-12 (HBU 2000). Electric conductivity was measured with Mettler Toledo Seven Easy with Mettler Toledo Inlab ${ }^{\circledR} 731$ probe, following the directions of DIN ISO 11265 (HBU 2000). Soil moisture was determined by calculating the loss on ignition, using a muffle furnace.
Statistical analyses

We used one-way ANOVAs followed by Tukey's HSD test to identify significant differences in shoot length, soil $\mathrm{pH}(\mathrm{CaCl})$ at $0-10 \mathrm{~cm}$, and soil moisture content between the sites. Leaf $\mathrm{C}: \mathrm{N}$ ratios, leaf carbonate content, and leaf nitrogen content, as well as the other soil parameters, were not normally distributed, as revealed by Shapiro-Wilk normality tests. Therefore, nonparametric tests were required for comparison between the sites. We used KruskalWallis tests followed by Dunn's tests (Dunn 1964) with adjusted p-values for multiple comparisons with the Benjamini-Hochberg method (Benjamini and Hochberg 1995), with the package 'dunn.test' (Dinno 2017) to compare these factors between the different sites.

We used linear mixed-effects model analyses, in which we compared climate-growth models (Table 1) with a null model, to test the influence of seasonal climate on growth. We standardized both the climate and raw individual shrub shoot length series before the analyses through subtraction of their means, followed by a division by their standard deviations. Annual shoot lengths of the individual shrubs were included in the models as the response variable and the seasonal climate variables (previous summer, previous autumn, winter, spring, summer, and autumn) were included as fixed effects. In addition, an autocorrelation structure (AR1, autoregressive process of order one) was included in each model. Random intercepts were included in the models for each year to account for spatially correlated environmental conditions not captured by the fixed effects. In total, we compared 30 climate models (Table 1) with the null model, i.e. six seasons for five factors: air temperature, surface temperature, precipitation, scPDSI, and sunshine hours. We included seasonal surface temperatures, as we hypothesized that these might have a larger effect given the low stature of these dwarf shrubs. The null model was identical to the other models, but with a constant mean (i.e. 1) instead of the climate variables as fixed effect. The linear mixed-effect model analyses were executed with the R-package nlme (Pinheiro et al. 2017). We used maximum likelihood estimation for model comparison and restricted maximum likelihood estimation for slope estimates (Crawley 2013). We calculated marginal and conditional coefficients of determination values for each model using the 
Table 1 Predictors used as fixed effects in the linear mixed-effect model comparison analysis
Shoot length was the response variable and year was included as a random effect in all models

In each model, year was included as random effect on the intercept. In addition, an autocorrelation structure (AR1, autoregressive process of order one) was included in all models. Models were compared at the site level, across sites ('Spiekeroog'), and excluding site $\mathrm{D}$

$(' \mathrm{~A}+\mathrm{B}+\mathrm{C}$ ')

Prev. previous,

$P$ precipitation sum, $T$ mean air temperature, $\min \_T_{\text {surf }}$ minimum surface temperature, PDSI Palmer

Drought Severity Index, sun sunshine hours sum.

Seasons winter-Dec, Jan, Feb; Spring-Mar, Apr, May; Summer-Jun, Jul, Aug; Autumn-Sep, Oct, Nov

\begin{tabular}{|c|c|c|c|}
\hline Model & Predictor & Random effect (intercept) & Autocorrelation structure \\
\hline 1 & Prev. summer $\mathrm{P}$ & Year & AR1 \\
\hline 2 & Prev. autumn $\mathrm{P}$ & Year & AR1 \\
\hline 3 & Winter $\mathrm{P}$ & Year & AR1 \\
\hline 4 & Spring $\mathrm{P}$ & Year & AR1 \\
\hline 5 & Summer P & Year & AR1 \\
\hline 6 & Autumn P & Year & AR1 \\
\hline 7 & Prev. summer $\mathrm{T}$ & Year & AR1 \\
\hline 8 & Prev. autumn T & Year & AR1 \\
\hline 9 & Winter $\mathrm{T}$ & Year & AR1 \\
\hline 10 & Spring $\mathrm{T}$ & Year & AR1 \\
\hline 11 & Summer T & Year & AR1 \\
\hline 12 & Autumn T & Year & AR1 \\
\hline 13 & Prev. summer min_ $T_{\text {surf }}$ & Year & AR1 \\
\hline 14 & Prev. autumn min_ $\mathrm{T}_{\text {surf }}$ & Year & AR1 \\
\hline 15 & Winter min_ $T_{\text {surf }}$ & Year & AR1 \\
\hline 16 & Spring min_ $\mathrm{T}_{\text {surf }}$ & Year & AR1 \\
\hline 17 & Summer min_ $\mathrm{T}_{\text {surf }}$ & Year & AR1 \\
\hline 18 & Autumn min_ $\mathrm{T}_{\text {surf }}$ & Year & AR1 \\
\hline 19 & Prev. summer PDSI & Year & AR1 \\
\hline 20 & Prev. autumn PDSI & Year & AR1 \\
\hline 21 & Winter PDSI & Year & AR1 \\
\hline 22 & Spring PDSI & Year & AR1 \\
\hline 23 & Summer PDSI & Year & AR1 \\
\hline 24 & Autumn PDSI & Year & AR1 \\
\hline 25 & Prev. summer sun & Year & AR1 \\
\hline 26 & Prev. autumn sun & Year & AR1 \\
\hline 27 & Winter sun & Year & AR1 \\
\hline 28 & Spring sun & Year & AR1 \\
\hline 29 & Summer sun & Year & AR1 \\
\hline 30 & Autumn sun & Year & AR1 \\
\hline
\end{tabular}

r.squaredGLMM function of the MuMIn package v. 1.42.1 (Nakagawa and Schielzeth 2013). Values for the predictor effect plots were calculated with the R-package effects v. 4.1-4 (Fox and Weisberg 2018). Two samples were excluded from the climate-growth analyses, as annual shoot length growth of these shrubs could only be measured for the most recent year, and hence could not be standardized.

\section{Results}

The linear mixed-effect model analyses showed clear effects of specific climatic conditions in the Wadden
Sea on annual shoot growth length of E. nigrum at the three sites located in the natural dune ecosystems of Spiekeroog, i.e. sites A-C (Table 2, Fig. 2). At these sites models with autumn temperatures (both minimum surface and mean air), previous summer mean minimum surface temperatures as fixed factor and/ or models with summer precipitation as fixed factor better explained growth than the null model $(\Delta \mathrm{AIC}>$ 2 ). The autumn minimum surface temperature model was the best model at sites A-C, across Spiekeroog (A-D), and when analysed across sites A-C. Autumn and previous summer mean minimum surface temperatures had a negative effect on shoot length growth of E. nigrum, i.e. those models had a negative slope, 
Table 2 Statistics of the selected linear mixed-effect models

\begin{tabular}{|c|c|c|c|c|c|}
\hline Site & Selected model(s) & $\Delta \mathrm{AIC}$ & Slope (s.e.) & $\mathrm{m} R^{2}$ & $\overline{\mathrm{c} R^{2}}$ \\
\hline \multirow[t]{3}{*}{ A } & Autumn min_ $\mathrm{T}_{\text {surf }}$ & 4.69 & $-0.38(0.14)$ & 0.18 & 0.33 \\
\hline & Prev. summer min_ $\mathrm{T}_{\text {surf }}$ & 3.11 & $-0.36(0.16)$ & 0.15 & 0.34 \\
\hline & Autumn T & 2.82 & $-0.34(0.15)$ & 0.13 & 0.33 \\
\hline \multirow[t]{3}{*}{ B } & Autumn min_ $\mathrm{T}_{\text {surf }}$ & 6.14 & $-0.40(0.12)$ & 0.20 & 0.32 \\
\hline & Autumn T & 2.66 & $-0.34(0.16)$ & 0.13 & 0.32 \\
\hline & Summer P & 2.39 & $0.32(0.15)$ & 0.14 & 0.32 \\
\hline \multirow[t]{4}{*}{$\mathrm{C}$} & Autumn min_ $\mathrm{T}_{\text {surf }}$ & 7.09 & $-0.37(0.10)$ & 0.17 & 0.24 \\
\hline & Autumn T & 4.63 & $-0.34(0.12)$ & 0.13 & 0.23 \\
\hline & Summer P & 2.85 & $0.31(0.14)$ & 0.12 & 0.25 \\
\hline & Prev. summer min_ $\mathrm{T}_{\text {surf }}$ & 2.18 & $-0.29(0.14)$ & 0.10 & 0.26 \\
\hline $\mathrm{D}$ & - & - & - & - & - \\
\hline \multirow[t]{2}{*}{ Spiekeroog } & Autumn min_ $\mathrm{T}_{\text {surf }}$ & 5.83 & $-0.32(0.10)$ & 0.14 & 0.23 \\
\hline & Autumn T & 3.61 & $-0.29(0.12)$ & 0.10 & 0.23 \\
\hline \multirow[t]{3}{*}{$\mathrm{A}, \mathrm{B}, \mathrm{C}$} & Autumn min_ $\mathrm{T}_{\text {surf }}$ & 7.31 & $-0.38(0.10)$ & 0.18 & 0.28 \\
\hline & Autumn T & 4.14 & $-0.33(0.13)$ & 0.13 & 0.28 \\
\hline & Prev. summer min_ $\mathrm{T}_{\text {surf }}$ & 2.08 & $-0.30(0.15)$ & 0.11 & 0.30 \\
\hline
\end{tabular}

$\overline{A I C}$ Akaike Information Criterion; s.e. standard error; $m R^{2}$ marginal $\mathrm{R}^{2}$ (proportion of variance explained by fixed factor); $c R^{2}$ conditional $\mathrm{R}^{2}$ (proportion of variance explained by fixed and random factors). Selected models are models with AIC values of at least 2 lower than the corresponding null model. Prev. previous; $\min _{-} T_{\text {surf }}$ minimum surface temperature; $T$ mean air temperature; $P$ precipitation sum

while summer precipitation had a positive effect (Table 2, Fig. 2). None of the seasonal climate models significantly explained E. nigrum growth at site D. Additional model comparison analyses across sites, with random intercept for site and year (Table S1) or for site (Table S2), gave very similar results with the autumn minimum surface temperature model as the best model in both analyses.

Mean annual shoot length growth of Empetrum nigrum differed between the different developmental dune stages (Fig. 3). While the relatively younger sites A $\quad(48.9 \pm 27.8 \mathrm{~mm} ; \quad$ mean \pm s.d. $)$ and B $(47.8 \pm 23.3 \mathrm{~mm})$ showed similar shoot length growth, the relatively older sampling sites C $(41.2 \pm 22.6 \mathrm{~mm})$ and $\mathrm{D}$ showed decreasing shoot length growth with the shortest annual shoot length increments at sampling site D $(29.7 \pm 15.0 \mathrm{~mm})$.

$\mathrm{C}: \mathrm{N}$ ratios, carbon content, and nitrogen content in the green leaves formed in 2017 of Empetrum nigrum at the different developmental dune stages significantly differed, especially between site A and sites B, $\mathrm{C}$, and D. Leaf C:N ratios $(45.2 \pm 4.94)$ were the lowest and leaf nitrogen content $(1.20 \pm 0.141 \%)$ the highest at the youngest dune, site A. Between the grey and brown dunes of Spiekeroog, sites B-D, there were no differences in leaf $\mathrm{C}: \mathrm{N}$ ratios (between $59.5 \pm 6.51$ and $63.9 \pm 8.81$ ) and leaf nitrogen content (Fig. 4; between $0.86 \pm 0.12$ and $0.93 \pm 0.10)$. Leaf carbon content was lowest at site A $(53.5 \pm 0.85 \%)$ and highest at site $\mathrm{C}(54.8 \pm 0.91)$, with intermediate values at site $\mathrm{D}(54.1 \pm 0.73)$. At site $\mathrm{B}$, leaf carbon content was lower $(53.7 \pm 0.58)$ than that at site $\mathrm{C}$, but it did not differ from that found at site A or D.

We found pronounced differences between the four locations regarding the soil characteristics within the natural dune ecosystem of Spiekeroog (Fig. 5). The youngest sampling location A (established from 1938 to 1960) had higher $\mathrm{pH}$ values in the three depths, both for $\mathrm{H}_{2} \mathrm{O}$ and $\mathrm{CaCl}_{2}$, compared to the other three sampling locations (B: 1841-1938, C and D: 1738-1841) (Fig. 5). The results for conductivity showed the lowest values at the youngest site $A$ across all depths $(0-30 \mathrm{~cm})$, and was lower in $\mathrm{A}$ than in $\mathrm{B}$ at 0-10 cm depth, as well as lower in A than in both $\mathrm{C}$ and $\mathrm{D}$ at $20-30 \mathrm{~cm}$ depth. Soil moisture did not differ between the sites. 


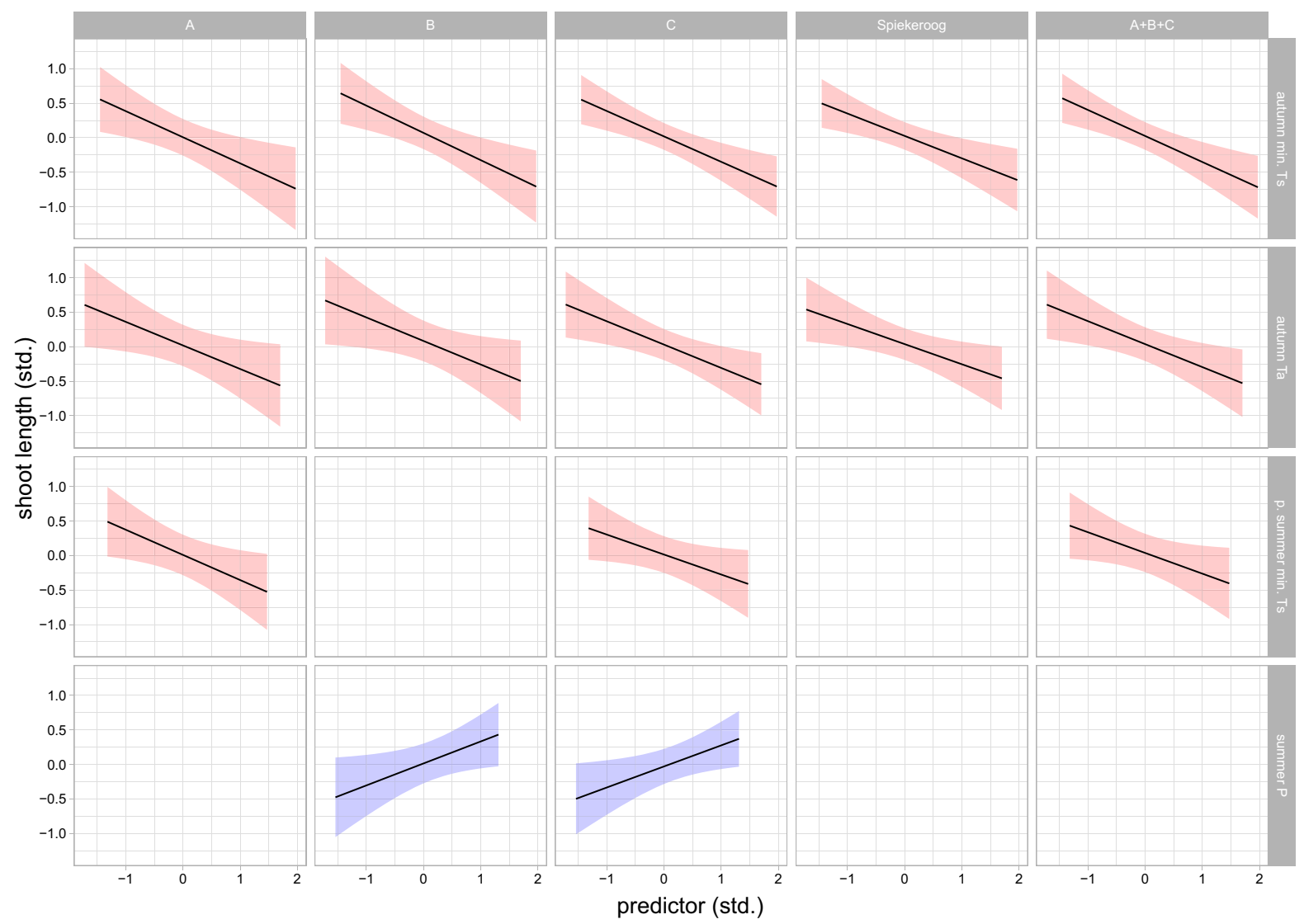

Fig. 2 Effect plots of the predictors for the selected models, i.e. the models with AIC-values of at least 2 lower than the corresponding null model. Model comparison was performed at the site level, across sites ('Spiekeroog'), and across sites A-

The results for the vegetation survey showed that all four sampling sites were dominated by Empetrum nigrum and the moss Pseudoscleropodium purum, with frequency values between $91.8-100 \%$, and $38.2-70.8 \%$, respectively, at all sites (Table 3 ). Along the gradient from younger to older dune stages, the number of plant species decreased and E. nigrum became more prevalent. In the relatively younger dunes at site A, for example, we observed the herb species Galium mollugo and six graminoid species, while in the older dunes, we observed a maximum of three graminoid species. The sedge Carex arenaria, and the grass Ammophila arenaria, typical graminoid species for the Empetrum vegetation type in the Wadden Sea area (Petersen et al. 2014) were present at most sites, although A. arenaria cover decreased with dune age and was no longer present at site D. The fern Polypodium vulgare was highly abundant at site A, but
C ('A + B + C'). min. Ts minimum surface temperature, $T a$ mean air temperature, $p$. previous, $P$ precipitation sum, std. standardized. Shaded areas represent \pm 1 standard error

its cover decreased with dune age with a frequency of only $1.6 \%$ at site D.

\section{Discussion}

Our results suggest that E. nigrum growth is drought sensitive at its European southern range margin. We found a negative response to autumn (surface) temperatures and previous summer surface temperatures and/or a positive response to summer precipitation of E. nigrum growth, except at the oldest dune with the strongest $E$. nigrum dominance. We hypothesize that this drought sensitivity may drive its northward retreat, which is also suggested by recent observations of E. nigrum dieback in northern Germany after the extreme drought in 2018 (Koch 2018a, b) and earlier model projections based on its 


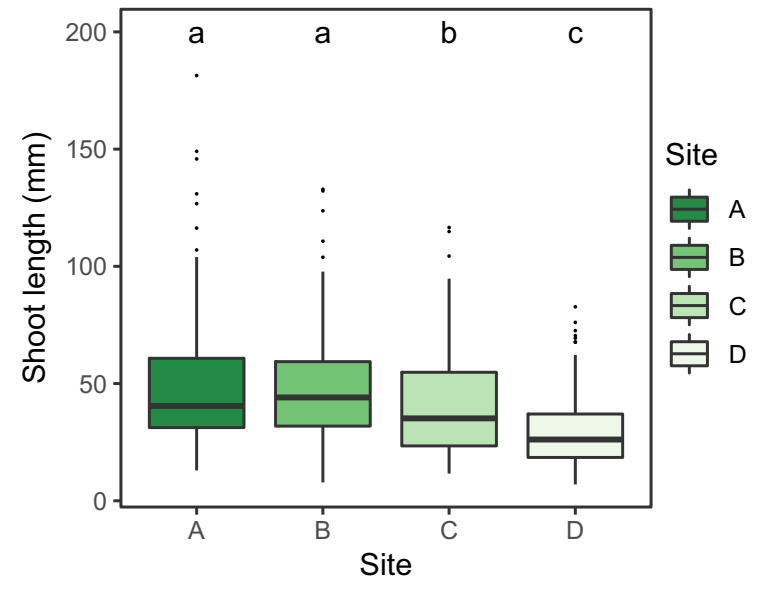

Fig. 3 Boxplots of annual Empetrum nigrum shoot length growth at the dune sites of different ages on Spiekeroog. Different letters above each box indicate different groups $(\mathrm{p}<0.05)$. Differences were tested for significance with oneway ANOVAs followed by Tukey's HSD tests

geographical and climatological distribution margins (Metzing 2010).

Our linear mixed-effect model analyses showed that annual shoot length growth was dependent on autumn temperatures, with higher temperatures suppressing growth. The growing season of E. nigrum is known to last well into autumn at more southern locations (Bell and Tallis 1973). Models with summer precipitation sums as predictor were significant at the later dune stage sites $\mathrm{B}$ and $\mathrm{C}$, with more precipitation leading to increased growth. Previous summer minimum surface temperatures negatively influenced the growth of E. nigrum at sites A and C. These factors all indicate that E. nigrum growth at its southern margin is sensitive to drought, mainly during autumn and summer. Still, we did not find an effect of seasonal self-calibrating Palmer Drought Severity Indices (scPDSI). The scPDSI is likely spatially too coarse and may not represent site-specific moisture availability (Zang et al. 2020). The observed drought sensitivity of $E$. nigrum growth may explain its dominance on north-facing slopes, and its relative absence on south-facing slopes in coastal ecosystems in Central Europe. On the warmer and drier southfacing slopes, E. nigrum is likely less competitive. Moreover, although E. nigrum has occasionally been observed to penetrate into the southern dune slopes on Spiekeroog, it cannot survive the poor water supply there during dry years (Mühl 1993).

As a consequence of the summer drought during 2018, extensive damage to the E. nigrum population was visible in the beginning of 2019 on Spiekeroog. The drought-related losses on E. nigrum on the island might be up to $15 \%$ of the formerly covered area (Lars Scheller, Nationalpark-Ranger Spiekeroog, 2020; pers. comm.). Similar areal-wide drought-induced dieback of E. nigrum was recently observed on the cooler North-Frisian Wadden Island Sylt, located further northeast near Denmark, after the drought of 2018 (Koch 2018a, b). Previously, only small-scale drought damage to E. nigrum populations was known from Sylt (Beinker 1998). Such drought-induced areal-wide dieback may well signal the ongoing and predicted (Metzing 2010) northward retreat of the species. The observed negative influence of autumn and previous summer surface temperatures and positive influence of summer precipitation is most likely the controlling factor at the boundary of the lowland southern range distribution of E. nigrum. It is restricted to the cooler regions of the northern hemisphere, and its more southern and low-elevation
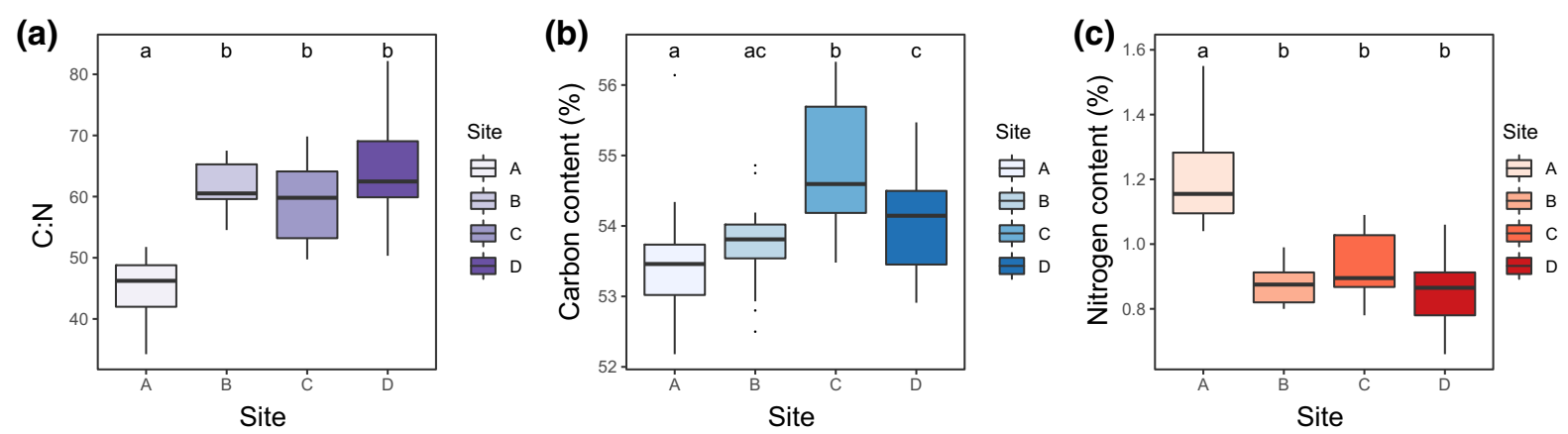

Fig. 4 Boxplots of C:N ratio, carbon content, and nitrogen content in green leaves formed in 2017 of Empetrum nigrum at the dune sites of different ages on Spiekeroog. Different letters above each box indicate different groups $(\mathrm{p}<0.05)$ 
(a)

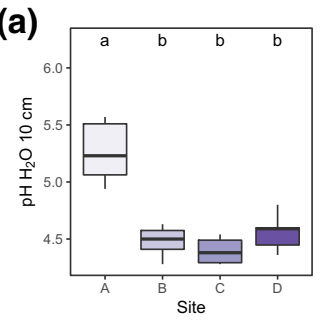

(e)

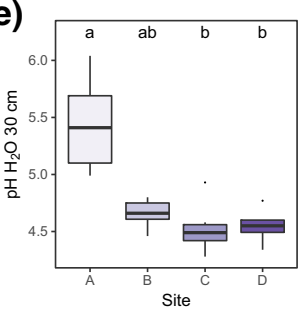

(i)

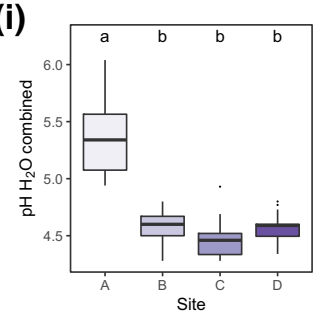

(b)

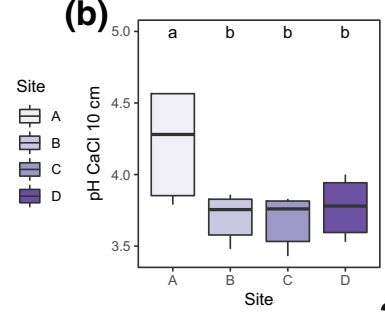

(f)
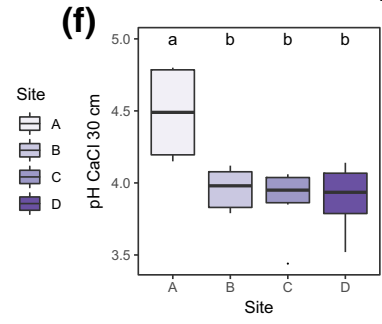

(j)
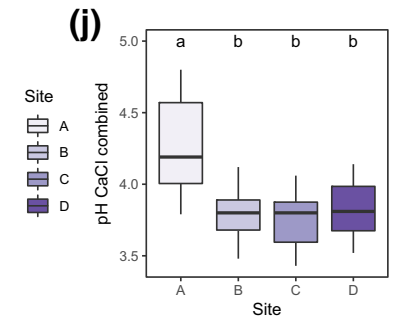

$0-10 \mathrm{~cm}$

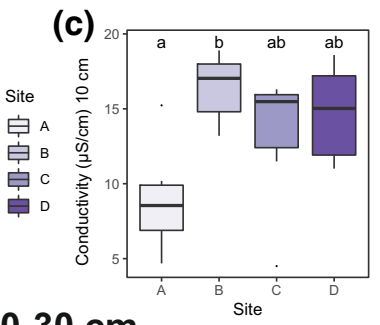

$20-30 \mathrm{~cm}$
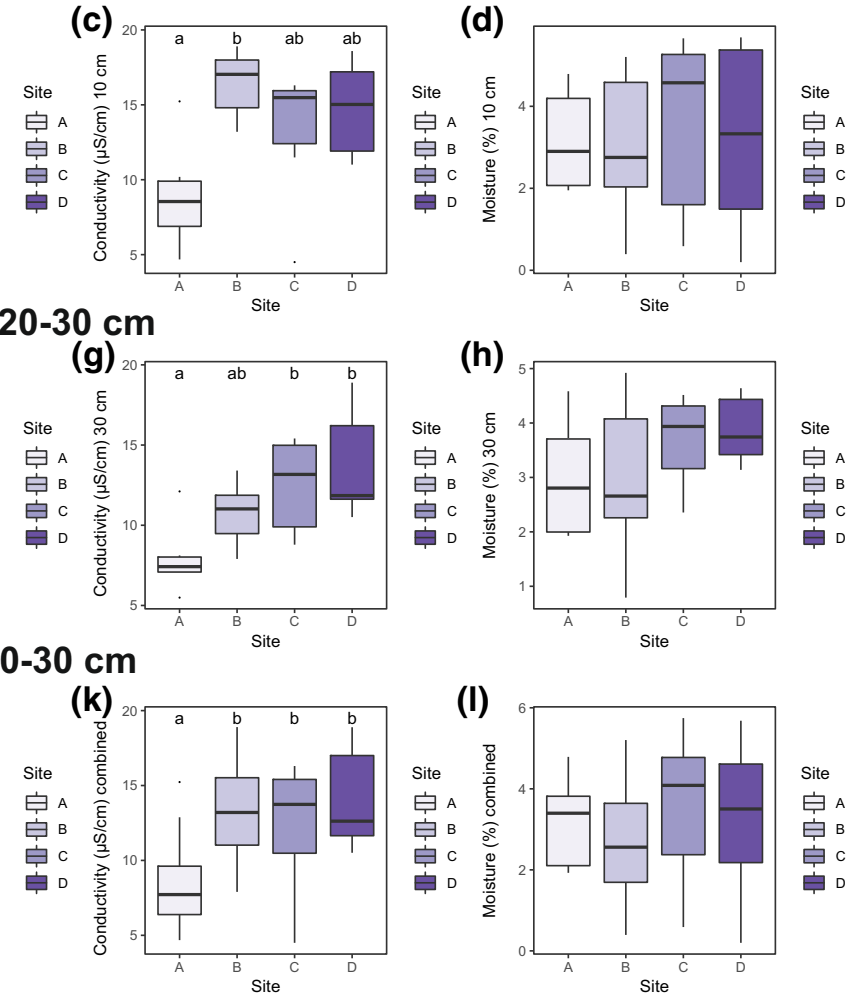

Fig. 5 Boxplots of the soil parameters measured at the dune sites of different ages on Spiekeroog: at 0-10 cm (a-d), 20-30 cm (e-h), and $0-30 \mathrm{~cm}(\mathbf{i}-\mathbf{l})$. Different letters above each box indicate different groups

occurrences in the British Isles have been linked with high precipitation levels (Bell and Tallis 1973). In the Netherlands, the species only occurs in areas with rainy and cloudy summers, or on shady sites and northfacing slopes (Barkman 1990). In contrast, Buizer et al. (2012) found increased annual shoot length growth of E. nigrum in response to passive warming with open-top chambers (OTCs) near its lowland southern range margin in a coastal dune valley near Bergen aan Zee, the Netherlands. However, although temperatures within OTCs were slightly higher in summer, this effect disappeared in September and daytime temperatures were in fact slightly lower in OTCs in the following weeks (Buizer et al. 2012). Moreover, wind sheltering may be more relevant than temperature, creating favourable growth conditions within OTCs (Marion et al. 1997).

In recent decades, lowland Empetrum populations have been retreating northwards in the Netherlands and Germany, cf. Buizer et al. (2012), while the species has expanded in Scandinavia (Vowles et al.
2017), north-eastern Siberia (Shevtsova et al. 2020), Quebec (Kitagawa et al. 2020), and High Arctic Svalbard (Buizer et al. 2012). In such colder Arctic and alpine tundra ecosystems, E. nigrum is dependent on the insulation by winter snow cover to survive severe winter frost (Bell and Tallis 1973). Drought stress is less likely to occur in such environments, as soil moisture content may remain high throughout the growing season as a result of snowmelt and low evaporation rates, even in the High Arctic polar desert, where growth of the related species Cassiope tetragona was found to be temperature driven (Weijers et al. 2017). Likewise, growth of this species did not respond to an experimentally doubling of the summer precipitation sum in High Arctic Svalbard (Weijers et al. 2013a). In an Arctic-wide synthesis study on climate sensitivity of shrub growth in tundra ecosystems, Myers-Smith et al. (2015) found greater sensitivity of shrub growth at sites with greater soil moisture content. Most of the relationships observed in the synthesis study between summer temperature 
Table 3 Vegetation frequencies for sites A-D

\begin{tabular}{|c|c|c|c|c|c|c|}
\hline Site A & Site B & Site C & Site D & Total & Species & $\begin{array}{l}\text { Typical vegetation } \\
\text { for Empetrum type } \\
\text { (TMAP: Petersen e }\end{array}$ \\
\hline
\end{tabular}

(TMAP; Petersen et al. 2014)

\begin{tabular}{|c|c|c|c|c|c|c|}
\hline \multicolumn{7}{|c|}{ Evergreen shrubs } \\
\hline 91.8 & 100 & 100 & 100 & 98.0 & Empetrum nigrum & \multirow[t]{2}{*}{$\checkmark$} \\
\hline 8.6 & 0 & 0 & 0 & 2.2 & Empetrum nigrum (dead) & \\
\hline \multicolumn{7}{|c|}{ Deciduous shrubs } \\
\hline 5.0 & 0 & 0 & 0 & 1.3 & Salix repens & \multirow[t]{4}{*}{$\checkmark$} \\
\hline 3.4 & 0 & 0 & 0 & 0.9 & Hippophaё rhamnoides & \\
\hline 3.4 & 0 & 0 & 0 & 0.9 & Rubus fructicosus agg & \\
\hline 2.4 & 0 & 0.4 & 0 & 0.7 & Sorbus aucuparia & \\
\hline \multicolumn{7}{|l|}{ Ferns } \\
\hline 96.6 & 64 & 40 & 1.6 & 50.6 & Polypodium vulgare & $\boldsymbol{V}$ \\
\hline 0 & 0 & 2.4 & 0 & 0.6 & Drypoteris dilatata & $\checkmark$ \\
\hline \multicolumn{7}{|c|}{ Graminoids } \\
\hline 61.8 & 10.6 & 2.4 & 0 & 18.7 & Ammophila arenaria & $\checkmark$ \\
\hline 41.2 & 12.8 & 20 & 22.2 & 24.1 & Carex arenaria & \multirow[t]{6}{*}{$\boldsymbol{v}$} \\
\hline 9.4 & 7.4 & 4.6 & 0 & 5.4 & Deschampsia flexuosa & \\
\hline 3.6 & 0 & 0 & 0 & 0.9 & Holcus lanatus & \\
\hline 0.6 & 0 & 0 & 0 & 0.2 & Luzula campestris & \\
\hline 0.4 & 0 & 0 & 0 & 0.1 & Phleum arenarium & \\
\hline 0 & 0.4 & 0 & 0 & 0.1 & Koeleria arenaria & \\
\hline \multicolumn{7}{|l|}{ Herbs } \\
\hline 4.8 & 0 & 0 & 0 & 1.2 & Galium mollugo & \\
\hline \multicolumn{7}{|c|}{ Lichens } \\
\hline 0 & 0.8 & 0 & 0 & 0.2 & Cladonia portentosa & $\boldsymbol{V}$ \\
\hline \multicolumn{7}{|c|}{ Mosses } \\
\hline 65.8 & 62.8 & 70.8 & 38.2 & 59.4 & Pseudoscleropodium purum & $\checkmark$ \\
\hline 18.6 & 8.0 & 33.6 & 6.0 & 16.6 & Pleurozium schreberi & $\checkmark$ \\
\hline 2.8 & 14 & 24.8 & 3.0 & 11.2 & Dicranum scoparium & $\boldsymbol{v}$ \\
\hline 3.8 & 0 & 0 & 0 & 1.0 & Rhytidiadelphus squarrosus & \\
\hline 1.0 & 0 & 0 & 0 & 0.3 & Hylocomnium splendens & $\boldsymbol{V}$ \\
\hline 16 & 13.2 & 3.8 & 0.6 & 8.4 & Litter & \\
\hline 0 & 0 & 0 & 0 & 0 & Dead wood & \\
\hline 0 & 0 & 0 & 0 & 0 & Mineral soil & \\
\hline 0 & 0 & 0 & 0 & 0 & Skeleton & \\
\hline 18 & 10 & 10 & 6 & 21 & Number of species & \\
\hline
\end{tabular}

Bold values are the number of species observed at each site and across sites

and shrub growth were, however, positive. Still, there are indications that higher temperatures result in lower shrub growth gains at drier (Ackerman et al. 2017) and warmer (Weijers et al. 2013b) sites. Moreover, the positive influence of summer temperatures on growth of E. nigrum declined at a near-treeline alpine ridge in the Central Norwegian Scandes and was replaced by a negative influence of May temperatures (Weijers et al. 2018). At this site, warming in recent decades has resulted in an advanced start of the growing season and an increased frequency of late frost events afterwards, which likely damaged the shrubs' newly developed 
soft tissues. Similar observations were made for Rhododendron ferrugineum shrub growth, i.e. less radial growth in response to earlier melt-out dates and associated late frost exposure at lower elevations in the French Alps (Francon et al. 2020). Moreover, Wipf et al. (2009) reported reduced growth of several shrub species, including E. nigrum, in response to advanced snowmelt at a near-treeline site in the Swiss Alps. Summarizing, we believe that the northward retreat of E. nigrum at its lowland southern range margin may be caused and accelerated by drought. In contrast, in Arctic-alpine tundra, summer temperature usually positively affects E. nigrum growth (Bär et al. 2008), which may explain its observed expansion in tundra ecosystems. Growth and expansion of E. nigrum and other shrub species in the Sub-Arctic and low-alpine tundra are, however, likely inhibited by frost damage, physiologically similar to drought damage, due to late frost after advanced snowmelt (Weijers et al. 2018) or extreme winter warming events (Bokhorst et al. 2009).

We found E. nigrum growth to be drought sensitive at all sites, except at site D. This may be related to the ability of E. nigrum to form a dense, even canopy, under which a relatively moist and mild microclimate persists, with lower maximum and higher minimum temperatures (Barkman 1990), making it less vulnerable to drought events. This effect is likely strongest at site D, where E. nigrum was most dominant. Different from sites A, B, and C, sampling site D is located on a dune complex within the southwestern salt marshes of the island, as this area was part of a smaller island called 'Lütjeoog' until it merged with Spiekeroog 300 years ago. The regular flooding of the salt marshes might cause, respectively, higher soil moisture values and thus lower local temperatures due to evaporation at site D, which might offer an explanation for the slowest growth rates found there and the lack of drought sensitivity.

In our study, the annual shoot length growth of Empetrum nigrum decreased with increasing dune age and concomitant development stages within a natural dune ecosystem on Spiekeroog.

While it is obvious that E. nigrum advanced and became more dominant in the later developmental stages in these natural dune ecosystems, its annual shoot length growth significantly decreased. This may be a consequence of the low $\mathrm{pH}$ values in the older dune stages. This phenomenon-increasing dominance, but slower growth-is in line with previous findings regarding the growth of E. nigrum under low $\mathrm{pH}$ values (Monni et al. 2000). Moreover, shoot length growth of E. nigrum may decrease with age, as was previously observed for another ericaceous dwarf shrub (Weijers et al. 2010; Weijers 2012), similar to age-related ring-width growth (e.g. Weijers et al. 2018). E. nigrum shrubs sampled in older dunes may have been older than those sampled in younger dunes.

The $\mathrm{pH}$ values found in the grey and brown dune soils are comparable to those reported along another very similar transect on Spiekeroog (Gerlach et al. 1994). Accordingly, the current grey dune stages will further decalcify and acidify, and transform into brown dunes as a consequence of braunification and podsolization (Pollmann et al. 2018), likely enabling E. nigrum, which is acidophilous (Elvebakk and Spjelkavik 1995). The dominance at the north-facing slopes in the dune ecosystems of Spiekeroog is likely partly the result of its ability to accommodate $\mathrm{pH}$ values as low as 2.5 (Bell and Tallis 1973). This observation is consistent with previous findings in nutrient-poor locations, where there is a negative correlation between species diversity and $\mathrm{pH}$ (Isermann 2005). Moreover, we found lower E. nigrum leaf $\mathrm{C} / \mathrm{N}$ ratios at the older dunes in comparison with the youngest dune site. Although we are unable to account for possible temporal variation in $\mathrm{C} / \mathrm{N}$ ratios due to the lack of data from the 2014 survey, this is in line with the lower net nitrogen mineralization rates in brown dunes and decreasing nitrogen turnover rates with increasing dune age, despite an increasing soil nitrogen pool; this was particularly apparent at E. nigrumdominated north slopes (Gerlach et al. 1994). In fact, E. nigrum may reduce the nitrogen supply of other plants as its acid litter accumulates on the soil surface, thus limiting turnover while recycling nitrogen through its ericoid mycorrhiza (Gerlach et al. 1994; Vowles and Björk 2019).

The soils in the dune systems of Spiekeroog are described as arenosols at different developmental stages (Pollmann et al. 2018, 2020). Arenosols are generally poorly developed soils, with high permeability and low nutrient content (Driessen et al. 2001). However, as long as $\mathrm{pH}$ values, nutrient availability and soil moisture are at a sufficient level for E. nigrum, it will be the dominant plant species, and its dense cover will protect the natural grey- and brown dune ecosystems from erosion. In various climate change scenarios, however, droughts are predicted to become 
more frequent and intense within the next decades, including Central Europe and Northern Germany (Schär et al. 2004; Lorenz et al. 2019), although Spinoni et al. (2015) showed some ambiguous results for Central Europe. Our results indicate that frequent heatwaves and drought events will severely affect the vegetation of the natural brown and grey dunes, and thus, the safety of the barrier islands within the Wadden Sea. A large-scale dieback of E. nigrum will create bare soil and make the dunes vulnerable to increased water and wind erosion. Such erosion will finally result in the loss of the protective characteristics of the natural dune ecosystems.

A long-term, sustainable protection strategy of coastal dune systems requires the protection of the natural dynamics and processes of dune ecosystems. Carefully conducted fine-scale long-term studies should be implemented to investigate how these natural systems react to ongoing and future global change.

\section{Conclusions}

Our findings show that climate change and an associated increased frequency of drought will likely negatively influence growth of E. nigrum shrubs near its southern distribution margin in European lowlands. Because of this and the recent observations of droughtinduced areal-wide dieback on Spiekeroog and on other Wadden islands, we hypothesize that droughts can have severe consequences for the composition and distribution of Empetrum heathlands, and may enable their northward retreat. We expect that drought events will change the dune ecosystems and vegetation on the Wadden Sea islands and in the coastal heathlands of Europe. The loss of a single-dominant species, in our case Empetrum nigrum, would have a large impact on these ecosystems. Consequently, further research and monitoring programs are needed to investigate the consequences and role of drought as a driver of the northward retreat of plant species.

Acknowledgements We would like to thank the NLWKN and the Lower Saxon Wadden Sea National Park Authority for permission to implement our study. The 'Umweltzentrum Wittbülten' and Swaantje Fock for support and use of their facilities during the field campaigns, and especially Carsten Heithecker for his support and incredible expertise about the Wadden Sea. Lars Scheller for his impressions on the recent development of E. nigrum on Spiekeroog. A cordial thanks to Cort Anderson for proofreading the manuscript. We would like to thank Maike Isermann for very helpful comments on the manuscript. We thank two anonymous reviewers for their constructive comments.

Author contributions $\mathrm{NH}$ and SW conceived and designed the study. NH, JM, and KZ collected soil samples. JM, KZ, and SW collected plant samples. Plant and soil analyses were carried out by JM and KZ. SW conducted the statistical analyses. NH and SW wrote the manuscript with contributions from JM and KZ. All authors revised the manuscript critically and approved the final manuscript for publication.

Funding Open Access funding enabled and organized by Projekt DEAL. The authors did not receive funding for the study.

Data availability Data is available at https://doi.org/10. 5061/dryad.j3tx95xch.

Code availability Code is available at https://doi.org/10. 5061/dryad.j3tx95xch.

\section{Compliance with ethical standards}

Conflict of interest The authors declare that they have no conflict of interest or competing interests.

Open Access This article is licensed under a Creative Commons Attribution 4.0 International License, which permits use, sharing, adaptation, distribution and reproduction in any medium or format, as long as you give appropriate credit to the original author(s) and the source, provide a link to the Creative Commons licence, and indicate if changes were made. The images or other third party material in this article are included in the article's Creative Commons licence, unless indicated otherwise in a credit line to the material. If material is not included in the article's Creative Commons licence and your intended use is not permitted by statutory regulation or exceeds the permitted use, you will need to obtain permission directly from the copyright holder. To view a copy of this licence, visit http://creativecommons.org/licenses/by/4.0/.

\section{References}

Ackerman D, Griffin D, Hobbie SE, Finlay JC (2017) Arctic shrub growth trajectories differ across soil moisture levels. Glob Change Biol 23:4294-4302

Bär A, Pape R, Bräuning A, Löffler J (2008) Growth-ring variations of dwarf shrubs reflect regional climate signals in alpine environments rather than topoclimatic differences. J Biogeogr 35:625-636

Barichivich J, Osborn TJ, Harris I, van der Schrier G, Jones PD (2019) Drought. In: Blunden J, Arndt DS (eds) State of the climate in 2018, S39-S40 
Barkman JJ (1990) Ecological differences between Calluna-and Empetrum-dominated dry heath communities in Drenthe, The Netherlands. Acta Bot Neerl 39:75-92

Beinker O (1998) Zur Vegetationskunde der Dünen im Listland der Insel Sylt. Kieler Not zur Pflanzenkunde Schlesw-Holst und Hambg 25(26):128-166

Bell JNB, Tallis JH (1973) Biological flora of the British Isles. Empetrum nigrum L. J Ecol 61:289-305

Benjamini Y, Hochberg Y (1995) Controlling the false discovery rate: a practical and powerful approach to multiple testing. J Royal Stat Soc 57:289-300

Bjorkman AD, Myers-Smith IH, Elmendorf SC, Normand S, Rüger N, Beck PSA, Blach-Overgaard A, Blok D, Cornelissen JHC, Forbes BC, Georges D, Goetz SJ, Guay KC, Henry GHR, HilleRisLambers J, Hollister RD, Karger DN, Kattge J, Manning P, Prevéy JS, Rixen C, SchaepmanStrub G, Thomas HJD, Vellend M, Wilmking M, Wipf S, Carbognani M, Hermanutz L, Lévesque E, Molau U, Petraglia A, Soudzilovskaia NA, Spasojevic MJ, Tomaselli M, Vowles T, Alatalo JM, Alexander HD, Anadon-Rosell A, Angers-Blondin S, Mt B, Berner L, Björk RG, Buchwal A, Buras A, Christie K, Cooper EJ, Dullinger S, Elberling B, Eskelinen A, Frei ER, Grau O, Grogan P, Hallinger M, Harper KA, Heijmans MMPD, Hudson J, Hülber K, Iturrate-Garcia M, Iversen CM, Jaroszynska F, Johnstone JF, Jørgensen RH, Kaarlejärvi E, Klady R, Kuleza S, Kulonen A, Lamarque LJ, Lantz T, Little CJ, Speed JDM, Michelsen A, Milbau A, Nabe-Nielsen J, Nielsen SS, Ninot JM, Oberbauer SF, Olofsson J, Onipchenko VG, Rumpf SB, Semenchuk P, Shetti R, Collier LS, Street LE, Suding KN, Tape KD, Trant A, Treier UA, Tremblay J-P, Tremblay M, Venn S, Weijers S, Zamin T, Boulanger-Lapointe N, Gould WA, Hik DS, Hofgaard A, Jónsdóttir IS, Jorgenson J, Klein J, Magnusson B, Tweedie C, Wookey PA, Bahn M, Blonder B, van Bodegom PM, Bond-Lamberty B, Campetella G, Cerabolini BEL, Chapin FS, Cornwell WK, Craine J, Dainese M, de Vries FT, Díaz S, Enquist BJ, Green W, Milla R, Niinemets Ü, Onoda Y, Ordoñez JC, Ozinga WA, Penuelas J, Poorter H, Poschlod P, Reich PB, Sandel B, Schamp B, Sheremetev S, Weiher E (2018) Plant functional trait change across a warming tundra biome. Nature 562:57-62

Bokhorst SF, Bjerke JW, Tømmervik H, Callaghan TV, Phoenix GK (2009) Winter warming events damage sub-Arctic vegetation: consistent evidence from an experimental manipulation and a natural event. J Ecol 97:1408-1415

Bose AK, Gessler A, Bolte A, Bottero A, Buras A, Cailleret M, Camarero JJ, Haeni M, Hereş A-M, Hevia A, Lévesque M, Linares JC, Martinez-Vilalta J, Matías L, Menzel A, Sánchez-Salguero R, Saurer M, Vennetier M, Ziche D, Rigling A (2020) Growth and resilience responses of Scots pine to extreme droughts across Europe depend on pre-drought growth conditions. Glob Change Biol. https://doi.org/10. 1111/GCB.15153

Boulanger-Lapointe N, Gérin-Lajoie J, Siegwart Collier L, Desrosiers S, Spiech C, Henry GHR, Hermanutz L, Lévesque E, Cuerrier A (2019) Berry plants and berry picking in Inuit Nunangat: traditions in a changing socio-ecological landscape. Hum Ecol 47:81-93. https://doi.org/10.1007/ s10745-018-0044-5
Buizer B, Weijers S, van Bodegom PM, Alsos IG, Eidesen PB, van Breda J, de Korte M, van Rijckevorsel J, Rozema J (2012) Range shifts and global warming: ecological responses of Empetrum nigrum L. to experimental warming at its northern (high Arctic) and southern (Atlantic) geographical range margin. Environ Res Lett 7:25501

Crawley MJ (2013) Mixed-effects models. In: Crawley MJ (ed) The R Book, 2nd edn. Wiley, Chichester, pp 681-714

Dinno A (2017) Dunn. test: Dunn's test of multiple comparisons using rank sums. $\mathrm{R}$ package version 1

Drachenfels Ov (2016) Kartierschlüssel für Biotoptypen in Niedersachsen unter besonderer Berücksichtigung der gesetzlich geschützten Biotope sowie der Lebensraumtypen von Anhang I der FFH-Richtlinie, Stand Juli 2016, 10. korrigierte Auflage 2018. NLWKN, Hannover

Driessen P, Deckers J, Spaargaren O, Nachtergaele F (2001) Lecture notes on the major soils of the world. Food and Agriculture Organization (FAO), Rome

Dunn OJ (1964) Multiple comparisons using rank sums. Technometrics 6:241-252

DWD (2019) Deutsche Wetterdienst. CDC - Climate Data Center. https://cdc.dwd.de/portal/. Accessed 14 May 2019

Ellenberg H, Leuschner C (2010) Vegetation Mitteleuropas mit den Alpen in ökologischer, dynamischer und historischer sicht, 6. völlig neu bearbeitete und stark erweiterte Auflage. Eugen Ulmer, Stuttgart

Elvebakk A, Spjelkavik S (1995) The ecology and distribution of Empetrum nigrum ssp. hermaphroditum on Svalbard and Jan Mayen. Nord J Bot 15:541-552

Floraweb (2013) Empetrum nigrum L. http://www.floraweb.de/ webkarten/karte.html?taxnr=2105. Accessed 20 January 2020

Fox J, Weisberg S (2018) Visualizing fit and lack of fit in complex regression models with predictor effect plots and partial residuals. J. Stat Soft 87:1-27

Francon L, Corona C, Till-Bottraud I, Choler P, Carlson BZ, Charrier G, Améglio T, Morin S, Eckert N, Roussel E, Lopez-Saez J, Stoffel M (2020) Assessing the effects of earlier snow melt-out on alpine shrub growth: the sooner the better? Ecol Indic 115:106455. http://www. sciencedirect.com/science/article/pii/ S1470160X20303927

Gerlach A (1993) Biogeochemistry of nitrogen in a coastal dune succession on Spiekeroog (Germany) and the impact of climate. Phytocoenologia 23:115-127

Gerlach A, Albers EA, Broedlin W (1994) Development of the nitrogen cycle in the soils of a coastal dune succession. Acta Bot Neerl 43:189-203

Green AJ, Lovas-Kiss Á, Stroud RA, Tierney N, Fox AD (2018) Plant dispersal by Canada geese in Arctic Greenland. Polar Res 37:1508268

Grinsted A, Jevrejeva S, Riva REM, Dahl-Jensen D (2015) Sea level rise projections for northern Europe under RCP8.5. Clim Res 64:15-23

HBU (2000) Handbuch der Bodenuntersuchung. Beuth, Berlin, Weinheim, Chichester

Isermann M (2005) Soil $\mathrm{pH}$ and species diversity in coastal dunes. Plant Ecol 178:111-120

Jevrejeva S, Jackson LP, Riva REM, Grinsted A, Moore JC (2016) Coastal sea level rise with warming above $2{ }^{\circ} \mathrm{C}$. Proc Natl Acad Sci USA 113:13342-13347 
Kitagawa R, Masumoto S, Nishizawa K, Kaneko R, Osono T, Hasegawa M, Uchida M, Mori AS (2020) Positive interaction facilitates landscape homogenization by shrub expansion in the forest-tundra ecotone. J Veg Sci 31:234-244

Koch L (2018a) Klimawandel wird das Bild unserer Insel verändern. http://www.natuerlichsylt.net/klimawandel-wirddas-bild-unserer-insel-veraendern/. Accessed 27 January 2020

Koch L (2018b) Trockenheit macht Dünenheide zu schaffen. http://www.natuerlichsylt.net/trockenheit-machtduenenheide-zu-schaffen/. Accessed 27 January 2020

Kratochwil A, Schwabe A (2001) Ökologie der Lebensgemeinschaften. Biozönologie; 168 Tabellen. Ulmer, Stuttgart

Lorenz R, Stalhandske Z, Fischer EM (2019) Detection of a climate change signal in extreme heat, heat stress, and cold in Europe from observations. Geophys Res Lett 46:8363-8374

Marion GM, Henry GHR, Freckman DW, Johnstone J, Jones G, Jones MH, Lévesque E, Molau U, Mølgaard P, Parsons AN, Svoboda J, Virginia RA (1997) Open-top designs for manipulating field temperature in high-latitude ecosystems. Glob Change Biol 3:20-32

Merkelbach J (2014) Growth characteristics of Empetrum nigrum along soil gradients of a natural dune system. B.Sc., University of Bonn, Bonn

Metzing D (2010) Global warming changes the terrestrial flora of the Wadden Sea. In: Marencic H, Eskildsen K, Farke H, Hedtkamp S (eds) Science for Nature Conservation and Management: The Wadden Sea Ecosystem and EU Directives. Proceedings of the 12th International Scientific Wadden Sea Symposium in Wilhelmshaven, Germany, 30 March - 3 April 2009. Wadden Sea Ecosystem No. 26. Common Wadden Sea Secretariat, Wilhelmshaven, pp 211-215

Metzing D, Gerlach A (2001) Climate change and coastal flora. In: Walther G-R, Burga CA, Edwards PJ (eds) "Fingerprints" of Climate Change: Adapted Behaviour and Shifting Species Ranges. Springer, Boston, pp 185-201

Monni S, Salemaa M, Millar N (2000) The tolerance of Empetrum nigrum to copper and nickel. Environ Pollut 109:221-229

Mühl M (1993) Zur Synsystematik der Krähenbeerheiden auf den Ostfriesischen Inseln. Drosera 93:11-32

Myers-Smith IH, Forbes BC, Wilmking M, Hallinger M, Lantz T, Blok D, Tape KD, Macias-Fauria M, Sass-Klaassen U, Lévesque E, Boudreau S, Ropars P, Hermanutz L, Trant A, Collier LS, Weijers S, Rozema J, Rayback SA, Schmidt NM, Schaepman-Strub G, Wipf S, Rixen C, Ménard CB, Venn S, Goetz S, Andreu-Hayles L, Elmendorf S, Ravolainen V, Welker JM, Grogan P, Epstein HE, Hik DS (2011) Shrub expansion in tundra ecosystems: dynamics, impacts and research priorities. Environ Res Lett 6:45509

Myers-Smith IH, Elmendorf SC, Beck PSA, Wilmking M, Hallinger M, Blok D, Tape KD, Rayback SA, MaciasFauria M, Forbes BC, Speed JDM, Boulanger-Lapointe N, Rixen C, Lévesque E, Schmidt NM, Baittinger C, Trant AJ, Hermanutz L, Collier LS, Dawes MA, Lantz TC, Weijers S, Jørgensen RH, Buchwal A, Buras A, Naito AT, Ravolainen V, Schaepman-Strub G, Wheeler JA, Wipf S, Guay
KC, Hik DS, Vellend M (2015) Climate sensitivity of shrub growth across the tundra biome. Nat Clim Change $5: 887-891$

Nakagawa S, Schielzeth H (2013) A general and simple method for obtaining R2 from generalized linear mixed-effects models. Methods Ecol Evol 4:133-142

Petersen J, Kers B, Stock M (2014) TMAP-typology of coastal vegetation in the Wadden sea area. Common Wadden Sea Secretariat, Wilhelmshaven

Pinheiro J, Bates D, DebRoy S, Sarkar D, R Core Team (2017) nlme: linear and nonlinear mixed effects models. R package version 3.1-131

Pollmann T, Junge B, Giani L (2018) Landscapes and soils of North Sea barrier islands: a comparative analysis of the old West and young East of Spiekeroog Island (Germany). Erdkunde 72:273-286

Pollmann T, Tsukamoto S, Frechen M, Giani L (2020) Rate of soil formation in Arenosols of dunes on Spiekeroog Island (Germany). Geoderma Reg 20:e00246

Pott R (1995) Farbatlas Nordseeküste und Nordseeinseln. Ausgewählte Beispiele aus der südlichen Nordsee in geobotanischer Sicht. Ulmer, Stuttgart

R Core Team (2019) R: A language and environment for statistical computing. R Foundation for Statistical Computing, Vienna

Röper T, Greskowiak J, Freund H, Massmann G (2013) Freshwater lens formation below juvenile dunes on a barrier island (Spiekeroog, Northwest Germany). Estuar Coast Shelf Sci 121:40-50

Schär C, Vidale PL, Lüthi D, Frei C, Häberli C, Liniger MA, Appenzeller C (2004) The role of increasing temperature variability in European summer heatwaves. Nature 427:332-336

Settele J, Scholes R, Betts R, Bunn S, Leadley P, Nepstad D, Overpeck JT, Taboada MA (2014) Terrestrial and inland water systems. In: Field CB, Barros VR, Dokken DJ, Mach KJ, Mastrandrea MD, Bilir TE, Chatterjee M, Ebi KL, Estrada YO, Genova RC, Girma B, Kissel ES, Levy AN, MacCracken S, Mastrandrea PR, White LL (eds) Climate Change 2014: impacts, adaptation, and vulnerability. Cambridge University Press, Cambridge, New York, pp 271-359

Shevtsova I, Heim B, Kruse S, Schröder J, Troeva EI, Pestryakova LA, Zakharov ES, Herzschuh U (2020) Strong shrub expansion in tundra-taiga, tree infilling in taiga and stable tundra in central Chukotka (north-eastern Siberia) between 2000 and 2017. Environ Res Lett 15:85006

Spinoni J, Naumann G, Vogt J (2015) Spatial patterns of European droughts under a moderate emission scenario. Adv Sci Res 12:179-186

Trilateral Wadden Sea Cooperation (2018) Trilateral research agenda for the Wadden Sea Region and its World Heritage Site. https://www.waddensea-worldheritage.org. Accessed 19 November 2019

Trouet V, van Oldenborgh GJ (2013) KNMI Climate Explorer. A web-based research tool for high-resolution paleoclimatology. Tree-Ring Res 69:3-13

Tybirk K, Nilsson M-C, Michelsen A, Kristensen HL, Shevtsova A, Tune Strandberg M, Johansson M, Nielsen KE, Riis-Nielsen T, Strandberg B, Johnsen I (2000) Nordic 
Empetrum dominated ecosystems: function and susceptibility to environmental changes. Ambio 29:90-97

van der Schrier G, Barichivich J, Briffa KR, Jones PD (2013) A scPDSI-based global data set of dry and wet spells for 1901-2009. J Geophys Res Atmos 118:4025-4048

Vowles T, Björk RG (2019) Implications of evergreen shrub expansion in the Arctic. J Ecol 107:650-655

Vowles T, Gunnarsson B, Molau U, Hickler T, Klemedtsson L, Björk RG (2017) Expansion of deciduous tall shrubs but not evergreen dwarf shrubs inhibited by reindeer in Scandes mountain range. J Ecol 105:1547-1561

Wadden Sea Board - Task Group Climate (2017) Trilateral climate change adaptation strategy. Monitoring report for the trilateral cooperation on the protection of the Wadden Sea. Common Wadden Sea Secretariat, Wilhelmshaven

Weijers S (2012) Climate reconstruction in the High Arctic: development and validation of a new tree-ring-like climate proxy. VU University, Amsterdam

Weijers S, Broekman R, Rozema J (2010) Dendrochronology in the High Arctic: July air temperatures reconstructed from annual shoot length growth of the circumarctic dwarf shrub Cassiope tetragona. Quat Sci Rev 29:3831-3842

Weijers S, Auliaherliaty L, van Logtestijn RSP, Rozema J (2013) Effects of manipulated precipitation and shading on Cassiope tetragona growth and carbon isotope discrimination: a High Arctic field study. Arct Antarct Alp Res 45:132-142
Weijers S, Wagner-Cremer F, Sass-Klaassen U, Broekman R, Rozema J (2013) Reconstructing High Arctic growing season intensity from shoot length growth of a dwarf shrub. The Holocene 23:721-731

Weijers S, Buchwal A, Blok D, Löffler J, Elberling B (2017) High Arctic summer warming tracked by increased Cassiope tetragona growth in the world's northernmost polar desert. Glob Change Biol 23:5006-5020

Weijers S, Beckers N, Löffler J (2018) Recent spring warming limits near-treeline deciduous and evergreen alpine dwarf shrub growth. Ecosphere 9:e02328

Wells N, Goddard S, Hayes MJ (2004) A self-calibrating Palmer drought severity index. J Clim 17:2335-2351

Wilson SD, Nilsson C (2009) Arctic alpine vegetation change over 20 years. Glob Change Biol 15:1676-1684

Wipf S, Stoeckli V, Bebi P (2009) Winter climate change in alpine tundra: plant responses to changes in snow depth and snowmelt timing. Clim Change 94:105-121. https://doi. org/10.1007/s10584-009-9546-x

Zang CS, Buras A, Esquivel-Muelbert A, Jump AS, Rigling A, Rammig A (2020) Standardized drought indices in ecological research: Why one size does not fit all. Glob Change Biol 26:322-324

Publisher's Note Springer Nature remains neutral with regard to jurisdictional claims in published maps and institutional affiliations. 